\title{
13. PRELIMINARY RESULTS OF PALEOTEMPERATURE RECONSTRUCTION USING THE MAGNESIUM TO CALCIUM RATIO OF DEEP-SEA OSTRACODE SHELLS FROM THE LATE QUATERNARY OF SITE 822, LEG 133 (WESTERN CORAL SEA) ${ }^{1}$
}

\author{
Thierry Corrège ${ }^{2}$
}

\begin{abstract}
Analyses of living benthic ostracodes collected in the Coral Sea show a direct relationship between water temperature and the $\mathrm{Mg} / \mathrm{Ca}$ ratio in the ostracode shells. Fossil ostracodes from Hole $822 \mathrm{~A}$ (western edge of the Queensland Trough) were analyzed for their $\mathrm{Mg}$ and $\mathrm{Ca}$ content, and paleotemperatures are inferred using equations derived from the modern material. The bottom-water temperature record from Site 822 , spanning the last $120,000 \mathrm{yr}$, indicates substantial cooling during glacial periods. It also documents important variations during an interval that is considered to correspond to isotopic stage 5. Although still preliminary, these results show that trace-element analyses of ostracode shells have a great potential for paleoceanographic studies.
\end{abstract}

\section{INTRODUCTION}

The main purpose of this study is to apply to late Quaternary microfossils the newly established method of paleotemperature reconstruction using trace-element analysis of benthic ostracode shells (Corrège and De Deckker, unpubl. data).

Site 822 , situated in $955 \mathrm{~m}$ of water on the western slope of the Queensland Trough, was selected for several reasons. Given the depth of Site 822 , there was a high probability that ostracodes required for this research would be encountered in the core samples. It was also anticipated that the change in water temperature registered between glacial and interglacial stages at that depth, compared to deeper sites, would be large enough for detection with the new technique. In addition, the position of Site 822 within the top portion of the Antarctic Intermediate Water makes it a good site for future study of the vertical movements through time of this particular watermass.

\section{MATERIAL AND METHODS}

\section{Material}

The top $27 \mathrm{~m}$ of Hole $822 \mathrm{~A}$, corresponding to lithologic Subunit IA, was sampled every $25 \mathrm{~cm}$. The sediment is a clayey bioclastic calcareous ooze that exhibits some change in color (see core description in Davies, McKenzie, Palmer-Julson, et al., 1991). Benthic ostracodes were extracted from each core sample for trace-element analysis. Ostracodes are microscopic crustaceans enclosed in a bivalve shell made of low-magnesium calcite. They are commonly used in paleoenvironmental studies (De Deckker et al., 1988).

\section{Methods}

\section{Preparation and Analysis}

For each core sample, $\sim 5 \mathrm{~cm}^{3}$ of sediment was placed in a solution of $3 \%$ hydrogen peroxide for at least two weeks to eliminate organic matter and to separate the clays. Each sample was then washed through a $100-\mu \mathrm{m}$ sieve and dried at $40^{\circ} \mathrm{C}$. The ostracodes were extracted using conventional techniques under a binocular microscope, and the following were observed in the faunal assemblages: presence of partial dissolution of the valves, faunal contamination by shallow-water taxa, and size sorting (see explanations below). Adults

\footnotetext{
'McKenzie, J.A., Davies, P.J., Palmer-Julson, A., et al., 1993. Proc. ODP, Sci. Results, 133: College Station, TX (Ocean Drilling Program).

${ }^{2}$ Department of Geology, Australian National University, Canberra, Australia.
}

of the characteristic deep-sea genera Krithe and Bythocypris were prepared for trace-element analyses. Individual valves were cleaned in an ultrasonic bath for a short period of time (typically $1-2 \mathrm{~s}$ to avoid breakage of the valves) and checked under a high-power microscope for any adhering particles. Only visibly cleaned specimens were used for chemical analysis. Ethanol was used as a medium for observation under the microscope and during cleaning procedures, because it has a lower viscosity and dries faster than water. Each individual clean valve was dissolved in $10 \mathrm{~mL}$ of high-purity $2 \% \mathrm{HNO}_{3}$ and analyzed for its $\mathrm{Ca}$ and $\mathrm{Mg}$ content. Analyses were conducted using a GBC 906 atomic absorption (AA) spectrophotometer. Concentrations of $\mathrm{Ca}$ were determined by flame analysis (detection limit: $0.02 \mathrm{ppm}$ ), using a cesium buffer, whereas concentrations of $\mathrm{Mg}$ were determined using both flame and graphite furnace analyses (detection limit on the furnace: $0.01 \mathrm{ppb}$ ). For each individual valve analyzed, three replicates were run for the two elements. The values of the standard deviation were always $<5 \%$ and typically on the order of $2 \%$ for $\mathrm{Mg}$. Repetitive runs using standards of different concentrations gave a typical error of $8 \%$ for both elements.

\section{Microscope Observations}

Supplementary observations of the ostracode fauna were tabulated (Fig. 1) as follows:

1. Dissolution index, with values theoretically ranging from 1 ( $100 \%$ of clear valves in pristine condition of preservation) to 5 (100\% of opaque/white valves). Usually, when ostracodes are alive, both valves are transparent. After the death of the animal, partial dissolution can affect the valves, which tend to become an opaque white. None of the 107 samples observed showed perfect preservation (value 1) or advanced dissolution (value 5) of the ostracode shells.

2. Contamination index, with a value of $1(0 \%-10 \%$ contaminants $)$ or 2 (between $10 \%$ and $50 \%$ contaminants). None of the samples contained more than $50 \%$ contamination by shallow-water ostracodes. In some areas of the Coral Sea, shallow material transported downslope can affect the composition of the sediment, to such an extent that shallow-water ostracodes can account for more than $50 \%$ of the total ostracode fauna (Corrège, unpubl. data).

3. Sorting index, with a value of 1 for a normal assemblage (all sizes, ranging from small juvenile valves to larger adult valves) and 2 for a sorted assemblage (Oertli, 1971).

The three indexes were plotted vs. sample depth to assess the reliability of the trace-element analysis (Fig. 1). Sorting and contami- 


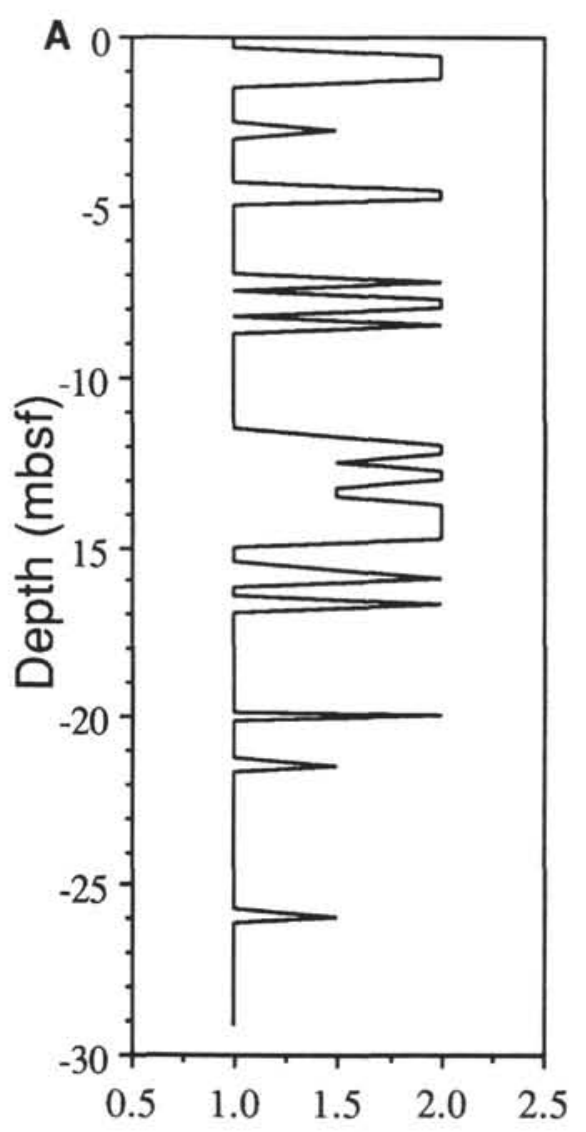

Sorting

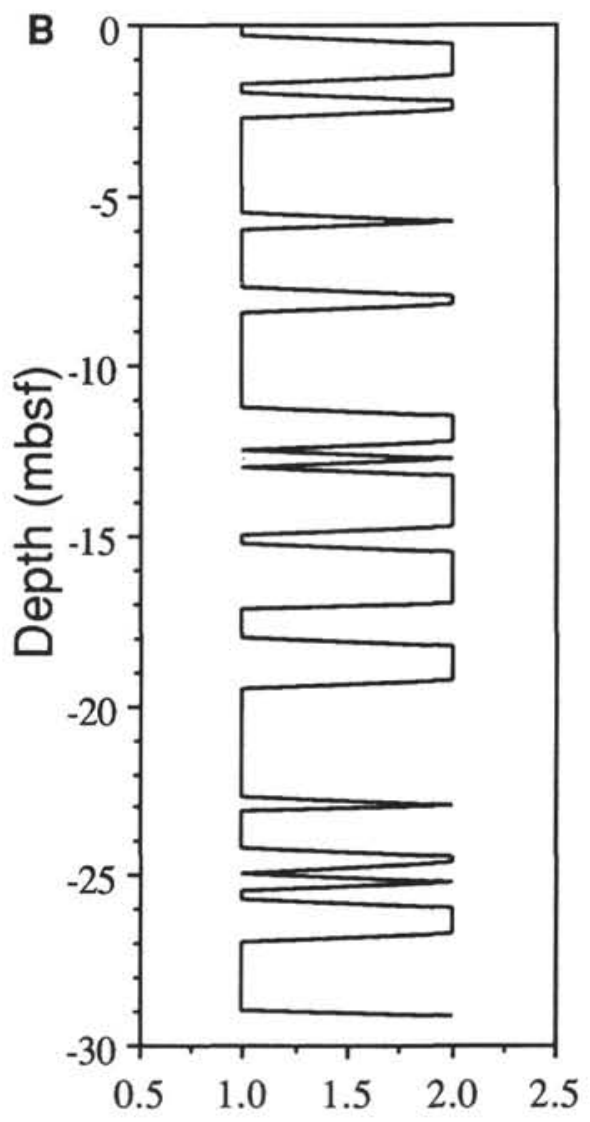

Contamination

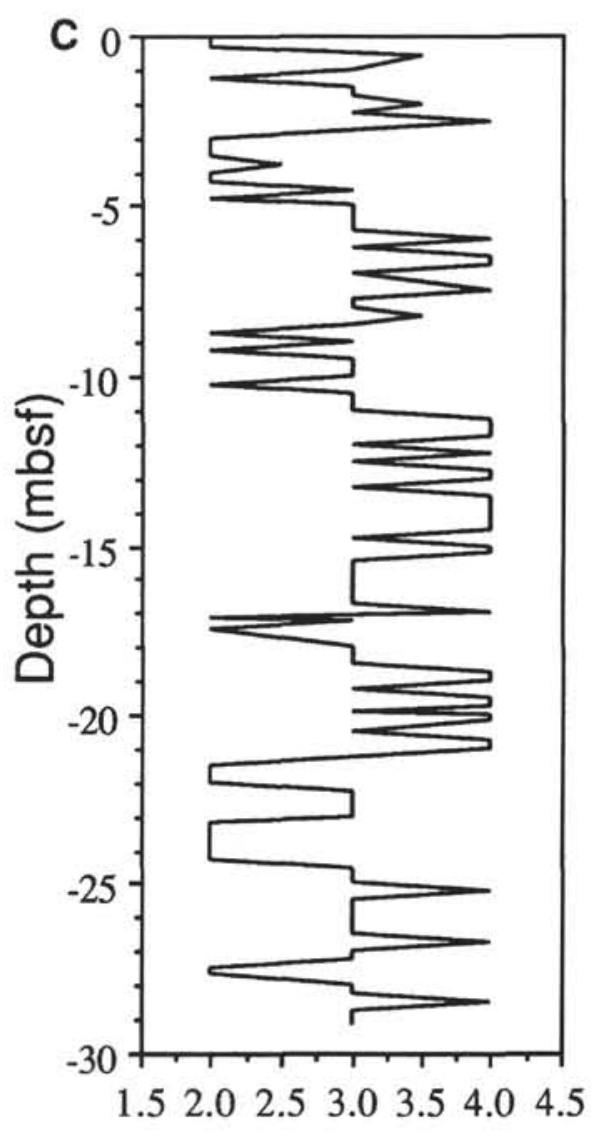

Dissolution

Figure 1. A. Plot of sorting index vs. sample depth in the core (see text for explanation). B. Plot of contamination index vs. sample depth in the core (see text for explanation). C. Plot of dissolution index vs. sample depth in the core (see text for explanation).

nation can explain unusually high paleotemperature values, because these parameters reflect downslope transport (although sorting can result from bottom currents as well). The record of dissolution is used to demonstrate that low $\mathrm{Mg} / \mathrm{Ca}$ ratios are not caused by partial dissolution of the ostracode valves, which may cause preferential loss of $\mathrm{Mg}$ (Chivas et al., 1986).

\section{RESULTS \\ Calibration}

We have established a direct relationship between the $\mathrm{Mg}$ content of individual ostracode valves (made of low- $\mathrm{Mg}$ calcite) and the temperature of the water in which the animal lives (Corrège and De Deckker, unpubl. data). Earlier attempts to establish such a relationship in the marine environment were somewhat inconclusive (Cadot and Kaesler, 1977; Bodergat, 1983), but work on nonmarine ostracodes yielded positive results (Chivas et al., 1983, 1986). By analyzing modern valves of Krithe and Bythocypris from grab samples collected from the seafloor at different water depths (and hence different temperatures) in the western Coral Sea, we were able to develop calibration curves to link the $\mathrm{Mg} / \mathrm{Ca}$ molar ratio of individual ostracode valves with water temperature (Fig. 2). This $\mathrm{Mg} / \mathrm{Ca}$ ratio in the ostracode valve is also affected to a much lesser extent by the $\mathrm{Mg} / \mathrm{Ca}$ content of ambient water, but this phenomenon is considered to have had a negligible effect during the late Quaternary because of the long residence time of $\mathrm{Mg}$ and $\mathrm{Ca}$ in seawater. From calibration curves we obtained using modern material, we derived the following equations: for Krithe,

$$
T=-2.56+462.96(\mathrm{Mg} / \mathrm{Ca})_{\text {valve, }} \mathrm{R}^{2}=0.900
$$

for Bythocypris,

$$
T=-6.45+364.16(\mathrm{Mg} / \mathrm{Ca})_{\text {valve, }} \mathrm{R}^{2}=0.942
$$

where $T=$ temperature and all $\mathrm{Mg} / \mathrm{Ca}$ ratios are molar ratios. These equations were calculated for $(\mathrm{Mg} / \mathrm{Ca})_{\text {seawater }}=5.2$ (standard value of modern seawater).

Different species grouped within the same genus have been shown to have similar partition coefficients (Chivas et al., 1986). Therefore, Equations 1 and 2 are valid for any given species of Krithe or Bythocypris, respectively. Indeed, several species of Krithe, and two species of Bythocypris were used in this study.

Each point on these calibration curves represents the mean value for the sample, with the associated standard deviation. I analyzed between 5 and 10 individual valves for each sample from a specific depth. It must be noted that analysis of modern material is currently in progress to refine these calibration curves, and therefore, these results should be considered to be only of a preliminary nature.

The calibration curves (Fig. 2) show that a certain spread in the data is to be expected. Thus, one must analyze at least five individual valves (and ideally $8-10$ valves)/sample and then average these $\mathrm{Mg} / \mathrm{Ca}$ values to get a representative ratio. Unfortunately, ostracodes suitable for trace-element analyses were scarce for the size of samples obtained from Hole $822 \mathrm{~A}$, and in most cases, I had to deal with one or two valves of the selected genera/sample. Nevertheless, some samples did yield a sufficient number of valves to permit a temperature reconstruction. 
A

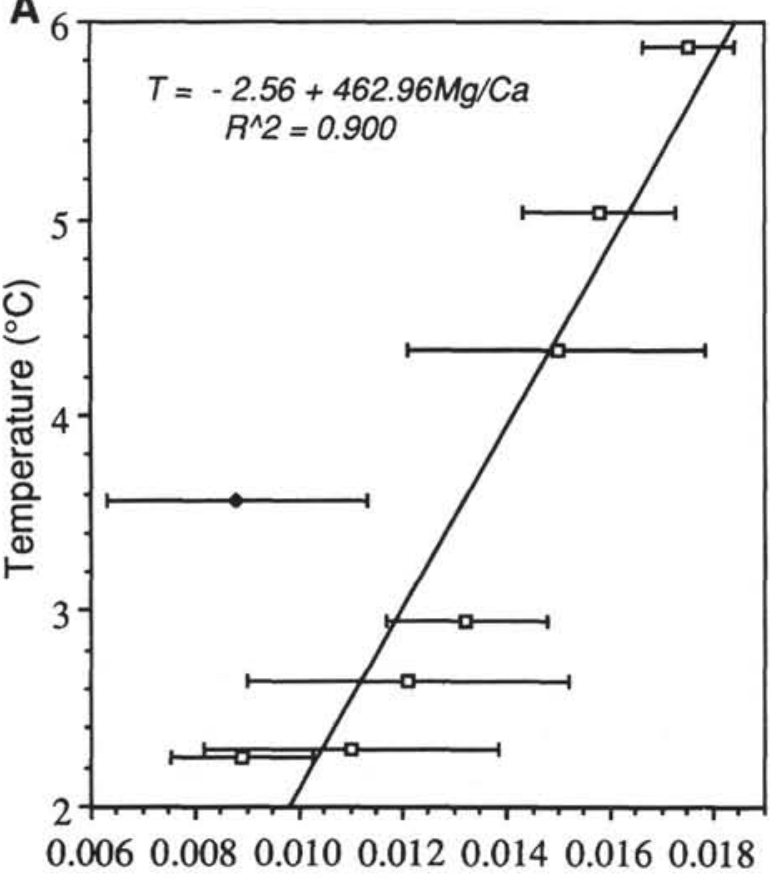

B

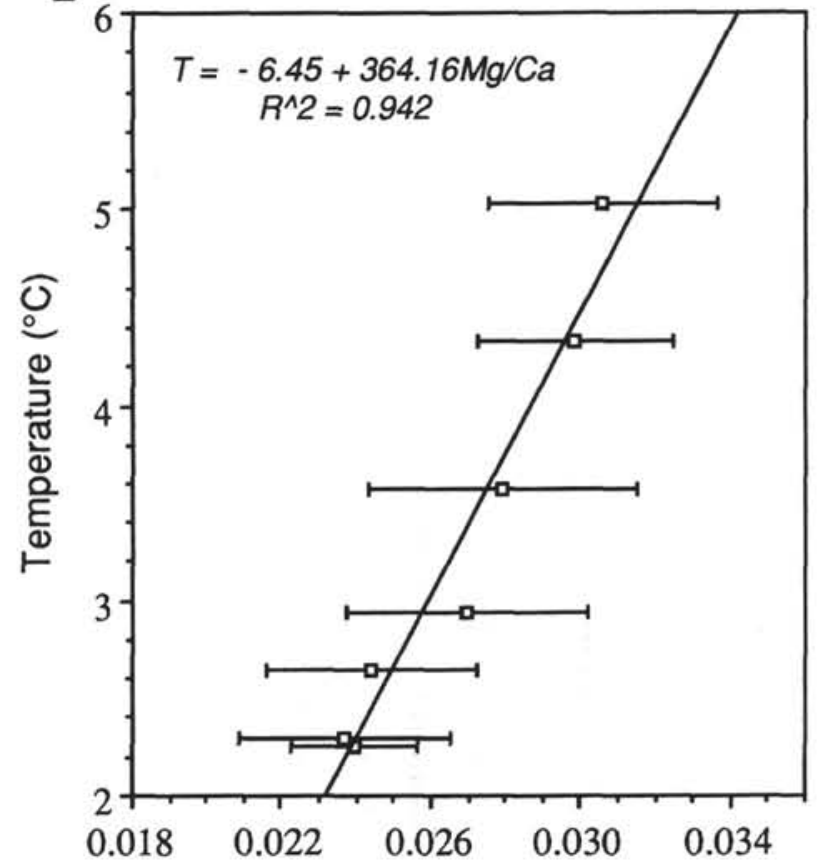

$\mathrm{Mg} / \mathrm{Ca}$ ratio

$\mathrm{Mg} / \mathrm{Ca}$ ratio

Figure 2. A. Calibration curve derived from analyses of $\mathrm{Mg} / \mathrm{Ca}$ molar ratios in modern Krithe from a range of water temperatures. The regression line is based on the mean $\mathrm{Mg} / \mathrm{Ca}$ value of seven samples (squares). The anomalous sample (diamond) was not included in the calculation of the regression line. Error bars indicate standard deviation of the mean for each sample. B. Calibration curve derived from analyses of $\mathrm{Mg} / \mathrm{Ca} \mathrm{molar}$ ratios in modern Bythocypris from a range of water temperatures (see $\mathbf{A}$ for explanations).

\section{Fossil Material}

Results from the trace-element analysis of the fossil ostracodes are given in Table 1 and Figure 3. For each individual ostracode analyzed, the $\mathrm{Mg} / \mathrm{Ca}$ molar ratio is given, together with the paleotemperature value derived from the equation that corresponds to the genus.

Of the 107 samples examined, $<60$ yielded suitable ostracodes for trace-element analysis. The best set of samples is available in the top $11 \mathrm{~m}$ of the hole (Fig. 4). Between 11 and 17 meters below seafloor (mbsf), high numbers of shallow ostracodes can be seen, which is indicative of downslope contamination. Between 17 and 27 mbsf Krithe and Bythocypris are too scarce to provide reliable temperature reconstructions.

One encouraging result is that in the case of samples containing both Krithe and Bythocypris, the temperature estimates obtained from the two ostracode genera frequently give similar values.

If only one valve is analyzed, the typical error of the paleotemperature value is of the order of $\pm 1^{\circ} \mathrm{C}$. In the case of samples having three or four valves analyzed, this error is lowered to $\pm 0.6^{\circ}-0.5^{\circ} \mathrm{C}$, depending on the standard deviation.

One concern with this paleotemperature reconstruction is the absence of an age control. In the absence of oxygen-isotope data, the only biostratigraphic marker I could use was the pink form of Globigerinoides ruber, which disappeared $120,000 \mathrm{yr}$ ago (Thompson et al., 1979). This event is situated between 8.75 and 9.0 mbsf in Hole $822 \mathrm{~A}$, giving an average sedimentation rate of $7.5 \mathrm{~cm} / \mathrm{k} . \mathrm{y}$. for the top $9 \mathrm{~m}$ of the core. I used this sedimentation rate to derive an age model for the upper $9 \mathrm{~m}$ of Hole $822 \mathrm{~A}$. I am well aware of the inaccuracy of this model (variable sedimentation rate, top of the section probably missing because of disturbance during the positioning of the drill). However, in the absence of an alternative way of dating the core, this is all $\mathrm{I}$ can rely on.
The first sample containing more than two ostracodes is situated at $1.5 \mathrm{mbsf}$. It provides a paleotemperature of $4.9^{\circ} \mathrm{C}$, but shallow-water ostracodes are present in the sample. This may indicate that the ostracodes analyzed came from upslope, thus, from water warmer than the actual site of Hole 822A. The next reliable sample is situated at 4.25 mbsf, and it gives a paleotemperature of $4.3^{\circ} \mathrm{C}$. Between 1.5 and 4.25 mbsf, the general trend points to a cooling of the water. The age at 4.25 mbsf is interpreted to be $\sim 60,000 \mathrm{yr}$ ago, roughly corresponding to the middle of isotopic stage 3. Data indicate another cooling below 4.25 mbsf, then a warming down to $6.25 \mathrm{mbsf}$. According to my age model, this is where isotopic stage $5 \mathrm{a}(\sim 80,000 \mathrm{yr}$ ago $)$ is placed. Another cooling took place between 6.25 and $9.0 \mathrm{mbsf}$, before the temperature returned to $\sim 4.3^{\circ} \mathrm{C}$. This is where I document the first appearance of pink G. ruber in the core, thus dating this level at $120,000 \mathrm{yr}$ ago.

\section{DISCUSSION}

The present-day water temperature at Site 822 (water depth 955 $\mathrm{m}$ ) lies between $5.5^{\circ}$ and $4.5^{\circ} \mathrm{C}$ (estimated from a large database of bottom-water temperatures and temperature profiles from the western Coral Sea; Corrège, unpubl. data from various sources).

Examination of the paleotemperature curve in Figure 4 shows that most of the values lie below $5^{\circ} \mathrm{C}$, which would tend to indicate that the water was cooler during glacial times at Site 822 .

Because of the bathymetric position of Site 822 , one has to remember that the difference in sea level between glacial and interglacial times should also be taken into account when looking at the paleotemperature results. In the western Pacific Ocean, the last glacial lowstand was situated $130 \mathrm{~m}$ below the present sea level (Chappell and Shackleton, 1986). Today in the Coral Sea, the difference in temperature between 955 and $825 \mathrm{~m}$ is of the order of $0.7^{\circ} \mathrm{C}$ (taken from the above-mentioned database). This means that if bottom-water 
Table 1. Geochemical analyses of ostracode shells from Site 822.

\begin{tabular}{|c|c|c|c|c|c|c|c|}
\hline $\begin{array}{l}\text { Depth } \\
\text { (mbsf) }\end{array}$ & $\begin{array}{l}\text { Sample } \\
\text { code }\end{array}$ & $\underset{(\mathrm{meq} / \mathrm{L})}{\mathrm{Mg}}$ & $\begin{array}{c}\mathrm{Ca} \\
(\mathrm{meq} / \mathrm{L})\end{array}$ & $\mathrm{Mg} / \mathrm{Ca}$ & $\begin{array}{c}\mathrm{Mg} / \mathrm{Ca} \\
\text { mean }\end{array}$ & $\begin{array}{l}\text { St. dev. } \\
\mathrm{Mg} / \mathrm{Ca}\end{array}$ & $\begin{array}{c}\text { Temperature } \\
\left({ }^{\circ} \mathrm{C}\right)\end{array}$ \\
\hline 0.1 & $\mathrm{~K} 1 \mathrm{~A}$ & 0.000534 & 0.039743 & 0.013426 & 0.013082 & 0.000345 & 3.49 \\
\hline 0.1 & K1B & 0.000595 & 0.046736 & 0.012737 & & & \\
\hline 1.0 & $\mathrm{~K} 3 \mathrm{~A}$ & 0.000406 & 0.027840 & 0.014569 & 0.014569 & & 4.18 \\
\hline 1.5 & B5A & 0.001134 & 0.035840 & 0.031627 & 0.031180 & 0.002290 & 4.90 \\
\hline 1.5 & B5B & 0.001448 & 0.042928 & 0.033734 & & & \\
\hline 1.5 & B5C & 0.001127 & 0.040008 & 0.028178 & & & \\
\hline 1.75 & $\mathrm{~K} 6 \mathrm{~A}$ & 0.000911 & 0.066450 & 0.013716 & 0.013716 & & 3.79 \\
\hline 2.0 & K7A & 0.001277 & 0.111958 & 0.011405 & 0.011405 & & 2.72 \\
\hline 3.75 & $\mathrm{~K} 10 \mathrm{~A}$ & 0.000608 & 0.052625 & 0.011546 & 0.011546 & & 2.78 \\
\hline 4.0 & $\mathrm{~K} 11 \mathrm{~B}$ & 0.000745 & 0.059408 & 0.012538 & 0.012538 & & 3.24 \\
\hline 4.0 & B11A & 0.001138 & 0.040282 & 0.028254 & 0.027962 & 0.000292 & 3.73 \\
\hline 4.0 & B11B & 0.001365 & 0.049326 & 0.027670 & & & \\
\hline 4.25 & $\mathrm{~K} 12 \mathrm{~A}$ & 0.000975 & 0.058355 & 0.016702 & 0.014837 & 0.002446 & 4.31 \\
\hline 4.25 & $\mathrm{~K} 12 \mathrm{~B}$ & 0.000813 & 0.076302 & 0.010651 & & & \\
\hline 4.25 & $\mathrm{~K} 12 \mathrm{C}$ & 0.000645 & 0.039444 & 0.016343 & & & \\
\hline 4.25 & $\mathrm{~K} 12 \mathrm{D}$ & 0.000325 & 0.020793 & 0.015650 & & & \\
\hline 5.0 & $\mathrm{~B} 13 \mathrm{~A}$ & 0.001712 & 0.068017 & 0.025168 & 0.025168 & & 2.71 \\
\hline 5.25 & $\mathrm{~K} 14 \mathrm{~A}$ & 0.001208 & 0.095074 & 0.012701 & 0.012701 & & 3.32 \\
\hline 5.5 & $\mathrm{~K} 15 \mathrm{~A}$ & 0.000802 & 0.061734 & 0.012990 & 0.012990 & & 3.45 \\
\hline 6.25 & $\mathrm{~K} 16 \mathrm{~A}$ & 0.000827 & 0.067349 & 0.012274 & 0.015123 & 0.002706 & 4.44 \\
\hline 6.25 & $\mathrm{~K} 16 \mathrm{~B}$ & 0.000583 & 0.031074 & 0.018760 & & & \\
\hline 6.25 & $\mathrm{~K} 16 \mathrm{C}$ & 0.000680 & 0.047444 & 0.014335 & & & \\
\hline 6.5 & $\mathrm{~K} 17 \mathrm{~A}$ & 0.000659 & 0.050958 & 0.012923 & 0.013239 & 0.000316 & 3.57 \\
\hline 6.5 & $\mathrm{~K} 17 \mathrm{~B}$ & 0.000800 & 0.059049 & 0.013555 & & & \\
\hline 6.5 & $\mathrm{~B} 17 \mathrm{~A}$ & 0.002452 & 0.088241 & 0.027788 & 0.027788 & & 3.66 \\
\hline 6.75 & B $18 \mathrm{~A}$ & 0.001821 & 0.083280 & 0.021870 & 0.022012 & 0.000142 & 1.56 \\
\hline 6.75 & B18B & 0.001366 & 0.061679 & 0.022153 & & & \\
\hline 7.5 & $\mathrm{~B} 20 \mathrm{~A}$ & 0.002210 & 0.100015 & 0.022096 & 0.022230 & 0.000102 & 1.64 \\
\hline 7.5 & $\mathrm{~B} 20 \mathrm{~B}$ & 0.001710 & 0.076547 & 0.022343 & & & \\
\hline 7.5 & B20C & 0.002830 & 0.127176 & 0.022252 & & & \\
\hline 8.0 & $\mathrm{~K} 21 \mathrm{~A}$ & 0.000836 & 0.078364 & 0.010666 & 0.010666 & & 2.38 \\
\hline 8.25 & $\mathrm{~K} 22 \mathrm{~A}$ & 0.000592 & 0.055465 & 0.010677 & 0.010677 & & 2.38 \\
\hline 8.25 & B22A & 0.002691 & 0.098996 & 0.027184 & 0.026522 & 0.000662 & 3.20 \\
\hline 8.25 & B22 B & 0.003300 & 0.127620 & 0.025860 & & & \\
\hline 8.75 & $\mathrm{~K} 23 \mathrm{~A}$ & 0.000481 & 0.029297 & 0.016424 & 0.016424 & & 5.04 \\
\hline 9.0 & $\mathrm{~K} 24 \mathrm{~A}$ & 0.000600 & 0.039040 & 0.015367 & 0.014904 & 0.001071 & 4.34 \\
\hline 9.0 & $\mathrm{~K} 24 \mathrm{~B}$ & 0.000635 & 0.043027 & 0.014767 & & & \\
\hline 9.0 & $\mathrm{~K} 24 \mathrm{C}$ & 0.000802 & 0.060416 & 0.013274 & & & \\
\hline 9.0 & K24D & 0.000443 & 0.027311 & 0.016207 & & & \\
\hline 9.25 & $\mathrm{~K} 25 \mathrm{~A}$ & 0.000862 & 0.068651 & 0.012557 & 0.012557 & & 3.25 \\
\hline 9.25 & B25A & 0.002344 & 0.107686 & 0.021768 & 0.021768 & & 1.47 \\
\hline 9.5 & $\mathrm{~K} 26 \mathrm{~A}$ & 0.000620 & 0.052410 & 0.011829 & 0.011601 & 0.000228 & 2.81 \\
\hline 9.5 & K26B & 0.000635 & 0.055869 & 0.011373 & & & \\
\hline 9.75 & $\mathrm{~K} 27 \mathrm{~B}$ & 0.000620 & 0.039379 & 0.015743 & 0.015743 & & 4.73 \\
\hline 9.75 & B27A & 0.002872 & 0.094305 & 0.030450 & 0.030450 & & 4.63 \\
\hline 10.5 & B29A & 0.002216 & 0.076193 & 0.029086 & 0.029086 & & 4.14 \\
\hline 11.25 & K31A & 0.000861 & 0.065926 & 0.013053 & 0.013321 & 0.000268 & 3.60 \\
\hline 11.25 & $\mathrm{~K} 31 \mathrm{~B}$ & 0.001147 & 0.084438 & 0.013589 & & & \\
\hline 17.14 & $\mathrm{~K} 41 \mathrm{~A}$ & 0.000478 & 0.034707 & 0.013775 & 0.013775 & & 3.81 \\
\hline 17.5 & $\mathrm{~K} 42 \mathrm{~A}$ & 0.000358 & 0.024720 & 0.014473 & 0.014473 & & 4.14 \\
\hline 18.25 & $\mathrm{~K} 44 \mathrm{~A}$ & 0.000648 & 0.049047 & 0.013206 & 0.012342 & 0.000865 & 3.15 \\
\hline 18.25 & K44B & 0.000527 & 0.045957 & 0.011477 & & & \\
\hline 18.75 & $\mathrm{~K} 45 \mathrm{~A}$ & 0.000424 & 0.028663 & 0.014796 & 0.014796 & & 4.29 \\
\hline 19.9 & $\mathrm{~K} 46 \mathrm{~A}$ & 0.002745 & 0.091375 & 0.030042 & 0.030042 & & 4.49 \\
\hline 21.0 & B $47 \mathrm{~A}$ & 0.003455 & 0.143426 & 0.024086 & 0.024086 & & 2.32 \\
\hline 22.5 & K48B & 0.000962 & 0.063835 & 0.015075 & & & 4.42 \\
\hline 23.5 & $\mathrm{~K} 49 \mathrm{~A}$ & 0.000575 & 0.040896 & 0.014066 & 0.016134 & 0.002068 & 4.91 \\
\hline 23.5 & K50B & 0.000831 & 0.045668 & 0.018202 & & & \\
\hline 24.0 & B51A & 0.001038 & 0.039683 & 0.026154 & 0.026154 & & 3.07 \\
\hline 27.0 & K59A & 0.000601 & 0.054117 & 0.011114 & 0.011114 & & 2.58 \\
\hline
\end{tabular}

When more than one valve was analyzed in a sample, the mean $\mathrm{Mg} / \mathrm{Ca}$ and the associated standard deviation were calculated. For these samples, the paleotemperature was calculated from the mean $\mathrm{Mg} / \mathrm{Ca}$.

temperature at Site 822 had not changed between the last glacial and today, paleotemperature values for the last glacial should be around $5.2^{\circ}$ to $6.2^{\circ} \mathrm{C}$. My data demonstrate that this is clearly not the case, thus implying a cooling of the Coral Sea's intermediate waters.

Paleotemperature reconstructions from oxygen isotopic composition of benthic foraminifers show that the deep Pacific Ocean was between $1.5^{\circ}$ and $1.1^{\circ} \mathrm{C}$ cooler during the last glaciation (Chappell and Shackleton, 1986; Birchfield, 1987). My data indicate that the intermediate waters in the Coral Sea were also cooler during the last glacial episode, with a temperature gradient possibly higher than $2^{\circ} \mathrm{C}$.
The deadline for submitting this chapter forced me to use equations for paleotemperatures that are still at a preliminary stage. I am still in the process of analyzing modern samples that might slightly alter the present calibration curves used here. In particular, I expect that the slope of the calibration curves might be lower. This would tend to reduce the absolute difference between high $\mathrm{Mg} / \mathrm{Ca}$ ratios (indicative of high temperatures) and low $\mathrm{Mg} / \mathrm{Ca}$ ratios (indicative of low temperatures). One consequence would be to increase the values of temperature corresponding to low $\mathrm{Mg} / \mathrm{Ca}$ ratios. At the moment, the paleotemperature values at 6.75 and $7.50 \mathrm{mbsf}$ seem too low. To 


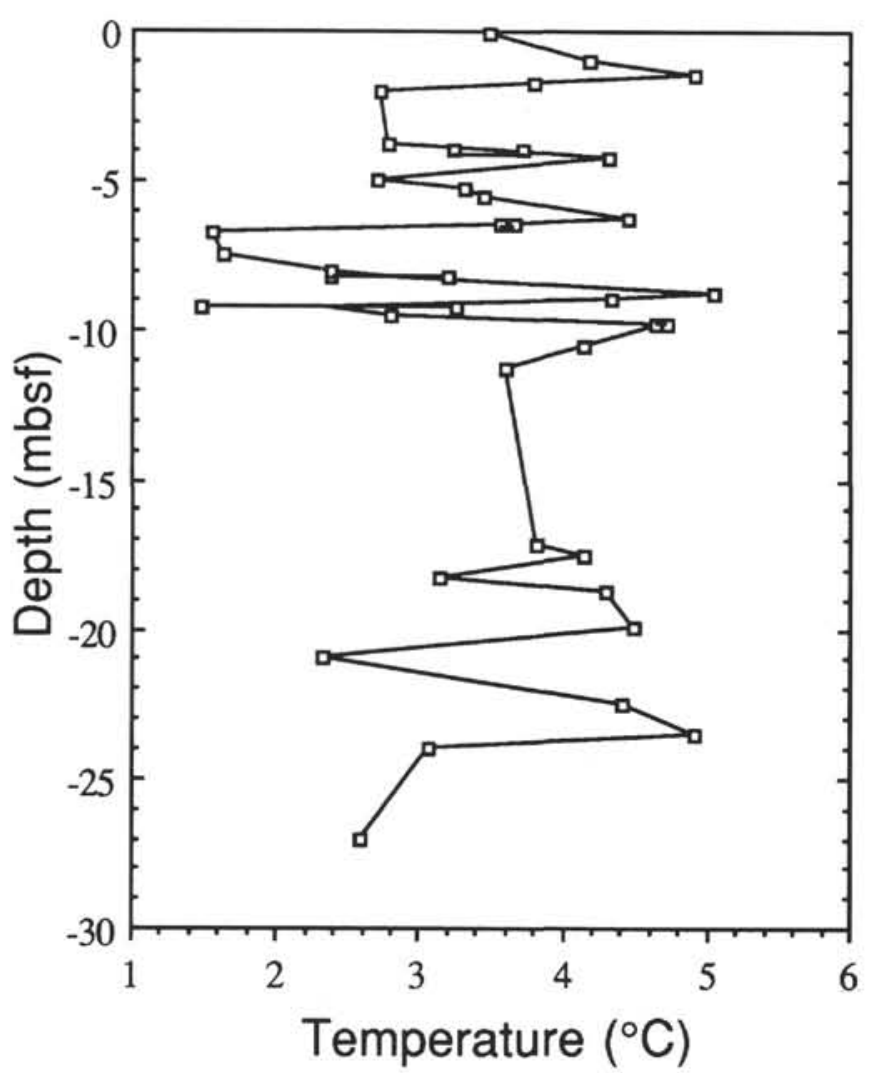

Figure 3. Paleotemperature curve for the upper $27 \mathrm{~m}$ of Hole 822A (see Table 1 for detail of values used to calculate each point).

obtain water temperatures lower than $2^{\circ} \mathrm{C}$ at a depth less than 1000 $\mathrm{m}$ in the Coral Sea appears improbable since such temperatures are found today only below $4000 \mathrm{~m}$. The only possible explanation could be the formation of coastal upwellings during glacial times, but there is no other evidence to support this hypothesis.

One intriguing result from my reconstruction is the important decrease in water temperature situated between the two "highs" at 9 and $6.5 \mathrm{mbsf}$ (corresponding respectively to isotopic stages $5 \mathrm{e}$ and $5 \mathrm{a}$, according to my age model). If correct, my data indicate that oceanographic variations within isotopic stage 5 were probably more marked in the tropical Pacific Ocean than originally thought (e.g., Shackleton, 1987).

Because low $\mathrm{Mg} / \mathrm{Ca}$ ratios (and, hence, low temperatures) occur mostly during times of high dissolution, one might think that the low ratios are in fact the result of partial dissolution of the ostracode shells, with a loss of $\mathrm{Mg}$. This is unlikely for several reasons. First, I tried to use only ostracodes that did not exhibit any sign of dissolution. Second, experience with freshwater and brackish ostracodes showed that $\mathrm{Mg}$ is lost quickly once dissolution of the shells occurs (De Deckker, pers. comm., 1992). Moreover, the correlation between low $\mathrm{Mg} / \mathrm{Ca}$ ratio and high dissolution is not always true, and one can get low $\mathrm{Mg} / \mathrm{Ca}$ ratios for samples that do not exhibit any sign of dissolution.

\section{CONCLUSIONS}

Although this work is still in progress, $\mathrm{I}$ postulate that the $\mathrm{Mg} / \mathrm{Ca}$ ratio of ostracode shells has great potential for reconstructing past bottom-water temperatures in the world oceans. This is the first geochemical method that depends only on temperature (at least for the late Quaternary, when $[\mathrm{Mg} / \mathrm{Ca}]_{\text {seawater }}$ remained unchanged), as opposed to oxygen isotope ratios. In fact, a coupling of the two methods should permit better assessment of the relative importance

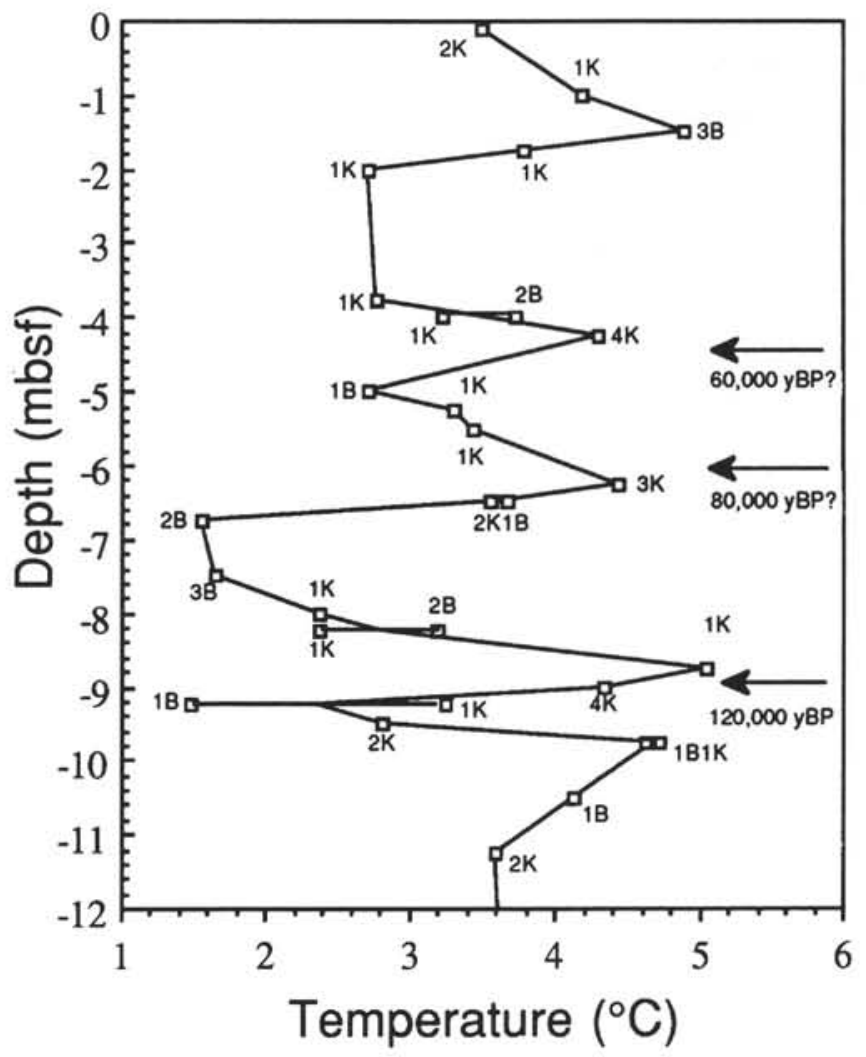

Figure 4. Reconstructed paleotemperature curve for the upper $12 \mathrm{~m}$ of Hole $822 \mathrm{~A}$. The 120,000 -yr-B.P. datum is based on the disappearance of the pink form of Globigerinoides ruber, and the other ages are extrapolated assuming a constant sedimentation rate. The number of valves and the genus analyzed are shown on each point of the curve $(\mathrm{K}=$ Krithe and $\mathrm{B}=$ Bythocypris $)$. See Table 1 for detail of values used to calculate each point.

of temperature and ice volume changes in the $\delta^{18} \mathrm{O}$ signal (Chivas et al., in press).

The main result from my investigation has been the documentation of a substantial change in temperature in the Queensland Trough during the last $120,000 \mathrm{yr}$. The amplitude of these variations is still difficult to estimate because of the few data available for Hole 822A, and also because the calibration curves still require additional data.

The next step of my research will involve analysis of ostracodes from deeper cores to document the temperature gradient difference in the Coral Sea between the present and the last glacial episode.

\section{ACKNOWLEDGMENTS}

Many thanks to Patrick De Deckker (ANU) for useful discussions and for correcting early versions of this manuscript. I also thank Peter Davies (University of Sydney), David Steel (ANU) for help with the AA, Dereck Burrage (AIMS), the captain and crew of the Franklin for help during collection of modern ostracodes, and Brian Funnell and Anne Marie Bodergat for their constructive review of this manuscript. This research is supported by an ANU Ph.D. scholarship.

\section{REFERENCES ${ }^{*}$}

Birchfield, G.E., 1987. Changes in deep-water $\delta^{18} \mathrm{O}$ and temperature from the last glacial maximum to present. Paleoceanography, 2(4):431-442.

\footnotetext{
Abbreviations for names of organizations and publications in ODP reference lists follow the style given in Chemical Abstracts Service Source Index (published by American
} Chemical Society). 


\section{T. CORRÈGE}

Bodergat, A.M.. 1983. Les ostracodes, témoins de leur environnement: approche chimique et écologique en milieu lagunaire et océanique. Docum. Lab. Géol. Lyon, 88:1-246.

Cadot, H.M., and Kaesler, R.L., 1977. Magnesium content of calcite in carapaces of benthic marine Ostracoda. Paleont. Contr. Univ. Kansas, $87: 1-23$.

Chappell, J., and Shackleton, N.J., 1986. Oxygen isotopes and sea level. Nature, 324:137-140.

Chivas, A.R., De Deckker, P., Shelley, J.M.G., 1983. Magnesium, strontium and barium partitioning in nonmarine ostracode shells and their use in paleoenvironmental reconstructions. A preliminary study. In Maddocks. R.F. (Ed.), Applications of Ostracoda: Houston (Uni. Houston Geosci.), 238-249.

, 1986. Magnesium and strontium in nonmarine ostracod shells as indicators of palaeosalinity and palaeotemperature. Hydrobiologia. 143:135-142.

Chivas, A.R., De Deckker, P., Cali, J.A., Chapman, A., Kiss, E., and Shelley, J.M.G., in press. Coupled stable-isotope and trace-element measurements of lacustrine carbonates as paleoclimatic indicators. Proc. Chapman Conf. on Continental Isotopic Indicators of Climate. Am. Geophys. Union.
Davies, PJ., McKenzie, J.A., Palmer-Julson, A., et al., 1991. Proc, ODP, Init. Repts., 133: College Station (Ocean Drilling Program).

De Deckker, P., Colin, J.P., Peypouquet, J.P., 1988. Ostracoda in the earth sciences: Amsterdam (Elsevier).

Oertli, H.J., 1971. The aspect of ostracode faunas. A possible new tool in petroleum sedimentology. Bull. Centre Recherche SNPA Suppl., 5:137151.

Shackleton, N.J., 1987. Oxygen isotopes, ice volume and sea level. Quat. Sci. Rev., 6:183-190.

Thompson, P.R., Duplessy, J.C., and Bé, A.H., 1979. Disappearance of pinkpigmented Globigerinoides ruber at 120,000 yr B.P. in the Indian and Pacific oceans. Nature, 280:554-558.

\section{Date of initial receipt: 1 June 1992 \\ Date of acceptance: 14 January 1993 \\ Ms 133B-222}

